\title{
Effect of Carotenoid Overproduction on Oxygen Tolerance of Nitrogen Fixation in Azospirillum brasilense Sp7
}

\author{
By ANTON HARTMANN ${ }^{1 *}+$ AND THOMAS HUREK ${ }^{2}$ \\ ${ }^{1}$ Department of Biochemistry, College of Agricultural and Life Sciences, University of \\ Wisconsin-Madison, Madison, WI 53706, USA \\ ${ }^{2}$ Institut für Biophysik, Universität Hannover, D-3000 Hannover 21, Federal Republic of \\ Germany
}

(Received 24 February 1988; revised 13 May 1988)

\begin{abstract}
Carotenoid-overproducing mutants of Azospirillum brasilense Sp7, which contained about 100 times more carotenoids than the wild-type, were obtained after nitrosoguanidine mutagenesis. Growth studies with one of these mutants in oxygen-controlled batch and continuous cultures revealed a slightly improved oxygen tolerance of nitrogen fixation in the mutant as compared to the wild-type. The production of carotenoids was greatly enhanced by increasing the oxygen concentration under nitrogen-deficient conditions. Although nitrogen fixation was severely inhibited by increased oxygen concentrations, in both the mutant and the wild-type, the mutant showed significantly greater efficiency of nitrogen fixation at $12 \mu \mathrm{M}$ dissolved oxygen, and it fixed five times more total nitrogen than the wild-type under these conditions. In conclusion, high levels of carotenoids slightly enhanced the oxygen tolerance of Azospirillum brasilense under conditions of oxygen stress, but did not extend the optimum $\mathrm{pO}_{2}$ for nitrogen fixation to higher oxygen concentrations.
\end{abstract}

\section{INTRODUCTION}

Azospirillum spp. are Gram-negative soil bacteria, which live in the rhizosphere of a variety of plants all over the world (Krieg \& Döbereiner, 1984; Patriquin et al., 1983). Nitrogen fixation by Azospirillum is strictly dependent on low oxygen concentrations (Day \& Döbereiner, 1976; Okon et al., 1977). In a nitrogen-free semisolid medium, Azospirillum grows as a subsurface pellicle; a pronounced aerotactic response helps the organism to cope with the oxygen problem (Barak et al., 1982).

Although oxygen is essential for aerobic life, it can pose a threat to cells if they are not adequately protected against toxic oxygen metabolites (Stouthamer et al., 1979; Halliwell \& Gutteridge, 1984; Krieg \& Hoffman, 1986). Toxic forms of oxygen (superoxide anion, ' $\mathrm{O}_{2}^{-}$and hydrogen peroxide) appear spontaneously or during metabolic activities. In nonenzymic reactions the very reactive radical ${ }^{\circ} \mathrm{OH}$ and singlet oxygen ${ }^{1} \mathrm{O}_{2}$ are formed. These may support autoxidation of unsaturated lipids, enzymes and redox-labile substrates.

Azospirillum brasilense has rather high respiratory activity, and it adapts to different oxygen concentrations (Bergersen \& Turner, 1980; Okon et al., 1983) and carries enzymes that detoxify superoxide and hydrogen peroxide (Nur et al., 1982; Moore et al., 1984). However, unlike Azotobacter spp., Azospirillum does not possess an efficient respiratory and conformational protection of nitrogenase (Robson \& Postgate, 1980; Yates \& Jones, 1974; Nelson \& Knowles, 1978; Hochman et al., 1987). Because the oxygen sensitivity of nitrogen fixation is a major

† Present address: Lehrstuhl für Mikrobiologie, Universität Bayreuth, Postfach 101251, D-8580 Bayreuth, Federal Republic of Germany.

0001-4727 (C) 1988 SGM 
limiting factor for growth of Azospirillum under nitrogen-deficient conditions, the improvement of its oxygen tolerance is of considerable interest. Nur et al. (1981) suggested a possible role of carotenoids in the protection of nitrogen fixation against oxygen damage in Azospirillum: after inhibition of carotenoid biosynthesis by diphenylamine, nitrogen fixation was reduced by oxygen stress. Many Azospirillum strains exhibit a faint pink colour from carotenoid pigments, and a few are coloured deep red or yellow by carotenoids (Tarrand et al., 1978; Nur et al., 1981). Carotenoids counteract photo-oxidative damage (Krinsky, 1979) and they actively quench singlet oxygen and have chain-breaking ability in radical-mediated autoxidation reactions (Burton \& Ingold, 1984); they also control lipid peroxidation at low oxygen concentrations (Burton \& Ingold, 1984).

The purpose of the present study was to determine the contribution of high levels of carotenoids to the oxygen tolerance of nitrogen fixation in $A$. brasilense. In a preliminary account, qualitative evidence was presented for the improvement of oxygen tolerance of nitrogen fixation in carotenoid-overproducing mutants of the low-pigment wild-type strain Sp7 (Hartmann et al., 1983). Here we report on the quantitative contribution of carotenoids to the oxygen tolerance of nitrogen fixation in oxygen-controlled batch and continuous-culture experiments.

\section{METHODS}

Organisms and conditions of mutagenesis. Wild-type strains of Azospirillum brasilense, Sp7 (ATCC 29145), which has a low carotenoid content, and the naturally red-pigmented Cd (ATCC 29710), were obtained from the American Type Culture Collection. Mutagenesis was performed with $N$-methyl- $N^{\prime}$-nitro- $N$-nitrosoguanidine (MNNG) according to Adelberg et al. (1965). A culture was pregrown in tryptone broth to the exponential growth phase, centrifuged and resuspended in Tris/maleate buffer to a cell density of $4 \times 10^{7} \mathrm{cells}^{-1}$. The cell

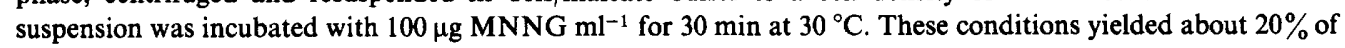
surviving bacteria. After removing the mutagen by three washings, the mutagenized cultures were grown overnight in tryptone broth for segregation of the mutations. About $10^{2}$ bacteria were plated on tryptone broth plates and incubated at $30^{\circ} \mathrm{C}$ at ambient oxygen concentration to screen for colour mutants.

Media and culture conditions. Batch cultures were grown in tryptone broth and minimal medium according to Albrecht \& Okon (1980). Growth in liquid, nitrogen-free minimal medium batch cultures was performed as described recently (Hartmann \& Burris, 1987). Dissolved oxygen concentrations were controlled by an oxystat. Continuous cultures were grown in a nitrogen-free synthetic malate $\left(5 \mathrm{~g}\right.$ potassium DL-malate $\left.1^{-1}\right)$ medium according to Hurek et al. (1987). Precultures were grown at $35^{\circ} \mathrm{C}$ in this medium plus (per litre) $0.5 \mathrm{~g} \mathrm{NH}_{4} \mathrm{Cl}$ and $0 \cdot 1 \mathrm{~g}$ yeast extract.

Dissolved-oxygen-controlled chemostat cultures. A 2-litre Biostat $\mathrm{V}$ fermenter equipped with temperature controller, $\mathrm{pH}$ controller and oxygen controller (Braun) was used. Temperature and $\mathrm{pH}$ were maintained constant at $35 \pm 0.2^{\circ} \mathrm{C}$ and at $7.0 \pm 0.05$ respectively. The culture volume was $1250 \mathrm{ml}$ and cultures were stirred at a constant rate of 400 r.p.m. Dissolved oxygen concentration was measured with an autoclavable Clark-type oxygen electrode (Ingold) and maintained constant at the desired levels with a relative accuracy of about $10 \%$. Maintenance of the desired equivalent partial pressures and the expression of the oxygen tension as actual oxygen concentration $(\mu \mathrm{M})$ were done according to Hurek et al. (1987). The culture vessel was inoculated with $2 \mathrm{ml}$ of a mid-exponential-phase preculture. Before the nutrient pump was started, batch growth was allowed to proceed at $4 \mu \mathrm{M}$ dissolved $\mathrm{O}_{2}$. Changes of culture conditions were followed by passage of 4 to 6 culture volumes through the vessel before measurements were made of a new steady state.

Extraction and characterization of carotenoids. Carotenoid pigments were extracted from the cells with acetone/ methanol $(7: 2, \mathrm{v} / \mathrm{v})$ according to Nur et al. (1981). Carotenoid concentrations were calculated from the absorbance at $500 \mathrm{~nm}$ of the acetone/methanol extract, using an absorption coefficient of 2500 for a $1 \%(\mathrm{w} / \mathrm{v})$ solution (Britton \& Goodwin, 1971). To determine individual pigments, the extracts were evaporated, redissolved in a small volume of chloroform, and chromatographed on silica gel thin-layer plates with methanol/chloroform $(7: 93, \mathrm{v} / \mathrm{v})$ as solvent. After extraction from the plates with methanol the visible spectra of the pigments were recorded with a Beckman spectrophotometer, model 25.

Analyses. Bacterial dry weight was determined as outlined by Kloss et al. (1983). Cellular protein was determined by the micro-Goa method (Bergersen, 1980), with bovine serum albumin as a reference standard. Total nitrogen was determined by Kjeldahl digestion by a procedure given by Bergersen (1980), and ammonia was measured enzymically by a test combination (no. 542946; Boehringer). Nitrogen-fixation activity was also measured by the acetylene reduction method (Burris, 1974). Ammonia in culture supernatants was determined by the phenol/hypochlorite method of Fawcett \& Scott (1960). 
Table 1. Carotenoid content and nitrogen fixation activity under oxygen stress conditions of $A$. brasilense $S p 7$ and carotenoid-overproducing mutants

\begin{tabular}{|c|c|c|}
\hline Strain & $\begin{array}{l}\text { Carotenoid content* } \\
{\left[\mu \mathrm{g}(\mathrm{mg} \text { protein })^{-1}\right]}\end{array}$ & $\begin{array}{c}\text { Nitrogenase activity } \dagger \\
\text { (nmol C }{ }_{2} \mathrm{H}_{4} \mathrm{~h}^{-1} \text { per } 10^{8} \text { cells) }\end{array}$ \\
\hline $\begin{array}{l}\text { A. brasilense } \mathrm{Sp} 7 \\
\text { Red-coloured mutant } \mathrm{C} 1 \\
\text { Red-coloured mutant } \mathrm{C} 2 \\
\text { Red-coloured mutant C3 }\end{array}$ & $\begin{array}{l}0.01 \\
0.97 \\
0.78 \\
1.04\end{array}$ & $\begin{array}{r}0 \\
134 \\
81 \\
124\end{array}$ \\
\hline
\end{tabular}

\section{RESULTS}

\section{Isolation and characterization of the mutants}

After mutagenesis of $A$. brasilense Sp7 with MNNG, red-coloured mutants were obtained with a frequency of $10^{-1}$ to $10^{-3}$. Red-pigmented colonies appeared after 3-5 d incubation at $30^{\circ} \mathrm{C}$ under air. Mutant colonies with different degrees of red pigmentation occurred, but only the deep red mutants are listed in Table 1 . In contrast to the wild-type, the mutants with a high level of carotenoid overproduction grew and fixed nitrogen under oxygen stress conditions, achieved according to Nur et al. (1981) (Table 1). Mutants with low or medium levels of carotenoids showed no consistent nitrogen fixation activity under oxygen stress (not shown). When the inoculum size was increased from $2 \times 10^{6}$ to $5 \times 10^{6} \mathrm{cells} \mathrm{m}^{-1}$ the wild-type also could grow and reduce acetylene. To prove that the pigment-overproducing mutants were derived from $\mathrm{Sp} 7$, a streptomycin- and rifampicin-resistant mutant of $\mathrm{Sp} 7$ was mutagenized. All coloured mutants revealed the double resistance.

The pigments of the mutant $\mathrm{Cl}$ were characterized further. When chromatographed on silica gel thin-layer plates (solvent: methanol/chloroform, $7: 93, \mathrm{v} / \mathrm{v}$ ) the extracted pigments had $R_{F}$ values of $0.25,0.40$ and 0.45 , similar to the main pigments of $A$. brasilense $\mathrm{Cd}$ (Nur et al., 1981). The pigments isolated from these bands gave carotenoid-like visible spectra; Fig. 1 compares the spectra of the pigment obtained from the spot of $R_{F} 0.45$ from mutant Cl (derived from the wild-type $\mathrm{Sp} 7$ ) with that of the wild-type $\mathrm{Cd}$. A fiftyfold concentrated extract of $\mathrm{Sp} 7$ revealed a red pigment which cochromatographed on thin-layer plates with the main carotenoid pigment of the mutant.

\section{Effect of oxygen stress on $A$. brasilense $S p 7$ and the mutant $\mathrm{Cl}$ in oxygen-controlled ammoniumlimited batch cultures}

To demonstrate improved oxygen tolerance due to carotenoid overproduction, the wild-type $\mathrm{Sp} 7$ and its carotenoid-overproducing mutant $\mathrm{Cl}$ were grown under nitrogen-fixing conditions at $4 \%$ air saturation (about $10 \mu \mathrm{M}$ dissolved $\mathrm{O}_{2}$ ); under these conditions derepression of nitrogen fixation was almost completely inhibited in $A$. brasilense $\mathrm{Sp} 7$ (A. Hartmann, unpublished results). During the rapid growth phase, when the initial low amount of ammonium was utilized, no difference in growth was observed between the strains (Fig. 2). Under nitrogen-deficient conditions (with continuing oxygen stress), however, the cells clumped and cellular protein decreased (Fig. 2). After a considerable period of adaptation, the mutant $\mathrm{C} 1$ recovered and resumed slow growth, giving a growth yield which exceeded that attainable from the limiting amount of ammonium. This oxygen-tolerant growth was preceded by a dramatic increase of carotenoids, which was evidently triggered by oxygen stress under conditions of nitrogen limitation. In the wild-type no measurable carotenoids were synthesized, and growth under 


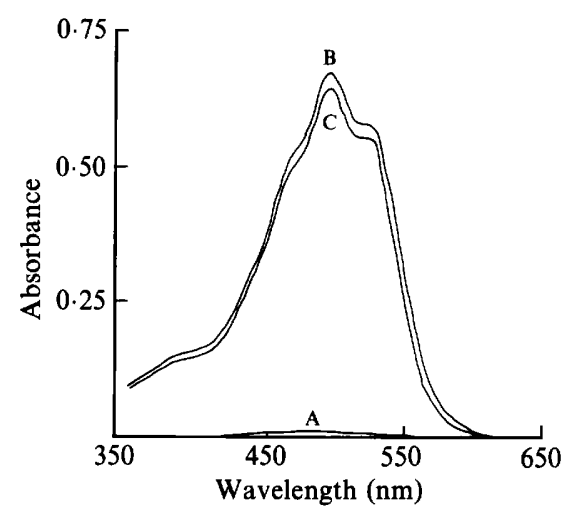

Fig. 1

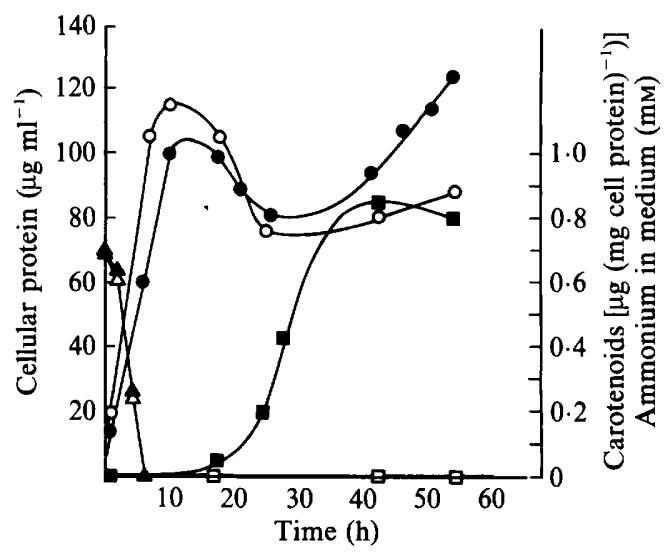

Fig. 2

Fig. 1. Visible spectra of acetone/methanol extracts of wild-type A. brasilense $\mathrm{Sp} 7$ (A), its red-coloured mutant $\mathrm{C} 1$ (B) and the naturally red-coloured wild-type $A$. brasilense $\mathrm{Cd}(\mathrm{C})$. Cells from $2 \mathrm{~d}$ old, stationary cultures were extracted and the spectra of the main red pigments were recorded as described in Methods.

Fig. 2. Growth (as cellular protein; $\bullet, O$ ) and carotenoid production $(\square, \square$ ), and ammonium concentration in the medium $(\Delta, \Delta)$, in ammonium-limited batch cultures of $A$. brasilense Sp 7 wild-type (open symbols) and its carotenoid-overproducing mutant $\mathrm{Cl}$ (filled symbols) at $10 \mu \mathrm{M}$ dissolved $\mathrm{O}_{2}$ concentration (about $4 \%$ air saturation).

Table 2. Effect of oxygen on growth and nitrogen fixation of $A$. brasilense $S p 7$ and its mutant $C 1$ grown on $\mathrm{N}_{2}$ in a chemostat at a dilution rate of $0.08 \mathrm{~h}^{-1}$

For each steady state, three subsamples were taken with intervals of one volume change. Analyses were done in duplicate. The experiments were done at least twice with very similar results.

\begin{tabular}{|c|c|c|c|c|c|c|c|}
\hline Strain & $\begin{array}{l}\text { Dissolved } \\
\mathrm{O}_{2} \text { concn } \\
\quad(\mu \mathrm{M})\end{array}$ & $\begin{array}{c}\text { Carotenoids } \\
\text { [ } \mathrm{g} \text { (mg cellular } \\
\left.\text { protein })^{-1}\right]\end{array}$ & $\begin{array}{c}\text { Malate in } \\
\text { supernatant } \\
\left(\mu \mathrm{g} \mathrm{ml}^{-1}\right)\end{array}$ & $\begin{array}{l}\text { Cell dry } \\
\text { weight } \\
\left(\mu \mathrm{gl}^{-1}\right)\end{array}$ & $\begin{array}{l}\text { Protein* } \\
\text { (\% of dry } \\
\text { weight) }\end{array}$ & $\begin{array}{c}\text { Total nitrogen } \\
\text { fixed } \\
\left(\mu \mathrm{g} \mathrm{ml}^{-1}\right)\end{array}$ & $\begin{array}{c}\text { Nitrogen-fixation } \\
\text { efficiency } \\
{[\mu \mathrm{g} \mathrm{N}(\mathrm{mg}} \\
\left.\text { malate })^{-1}\right]\end{array}$ \\
\hline Sp7 & $\begin{array}{r}1 \cdot 7 \\
7 \cdot 6 \\
13 \cdot 2 \\
16 \cdot 0\end{array}$ & $\begin{array}{l}\leqslant 0.01 \\
\leqslant 0.01 \\
\leqslant 0.01 \\
\leqslant 0.01\end{array}$ & $\begin{array}{l}\leqslant 0 \cdot 2 \\
\leqslant 0 \cdot 2 \\
902 \\
959\end{array}$ & $\begin{array}{r}177 \\
213 \\
4 \cdot 4 \\
4 \cdot 0\end{array}$ & $\begin{array}{r}45 \pm 4 \\
27 \pm 2 \\
14 \pm 1 \\
8 \pm 1\end{array}$ & $\begin{array}{l}12.5 \pm 1.0 \\
8.0 \pm 0.6 \\
0.08 \pm 0.006 \\
0.04 \pm 0.004\end{array}$ & $\begin{array}{r}12.5 \\
8.0 \\
0.8 \\
0.9\end{array}$ \\
\hline $\mathrm{Sp} 7 \mathrm{Cl}$ & $\begin{array}{r}1 \cdot 5 \\
8 \cdot 9 \\
12 \cdot 7 \\
17 \cdot 0\end{array}$ & $\begin{array}{l}0.25 \\
0.54 \\
1 \cdot 29 \\
3 \cdot 36\end{array}$ & $\begin{array}{l}\leqslant 0 \cdot 2 \\
\leqslant 0 \cdot 2 \\
850 \\
912\end{array}$ & $\begin{array}{r}183 \\
206 \\
23 \\
9\end{array}$ & $\begin{array}{r}48 \pm 4 \\
26 \pm 3 \\
14 \pm 1 \\
4 \pm 1\end{array}$ & $\begin{array}{c}13.2 \pm 1.1 \\
7.8 \pm 0.6 \\
0.43 \pm 0.03 \\
0.25 \pm 0.02\end{array}$ & $\begin{array}{r}13 \cdot 2 \\
7 \cdot 8 \\
2 \cdot 9 \\
2 \cdot 8\end{array}$ \\
\hline
\end{tabular}

oxygen stress was almost completely abolished. During the slow oxygen-tolerant growth of the mutant $\mathrm{Cl}$, only low acetylene reduction activities were measured (not shown). To evaluate the quantitative influence of high levels of carotenoids on nitrogen fixation activity during oxygen stress, $\mathrm{N}_{2}$-dependent continuous culture experiments and measurements of nitrogen fixation by direct means were performed.

\section{Effect of oxygen on $\mathrm{N}_{2}$-dependent growth of $A$. brasilense $S p 7$ and its carotenoid-overproducing mutant $C 1$ in continuous culture}

The growth of both strains in the absence of combined nitrogen was followed at a constant dilution rate (generation time, $8.7 \mathrm{~h}$ ) under various dissolved oxygen concentrations from about $2 \mu \mathrm{M}-\mathrm{O}_{2}$ to $17 \mu \mathrm{M}-\mathrm{O}_{2}$ (Table 2). Between 2 and $8 \mu \mathrm{M}-\mathrm{O}_{2}$ no malate $\left(\leqslant 0.2 \mu \mathrm{g} \mathrm{ml}^{-1}\right)$ was found in the supernatants, indicating that these steady-state cultures were malate limited. At these 
relatively low oxygen concentrations no differences were found between the strains in cell dry weight, malate in the supernatant, percentage protein of dry bacteria and total nitrogen fixed (Table 2). Increasing the dissolved oxygen concentration above $8 \mu \mathrm{M}-\mathrm{O}_{2}$ decreased nitrogen fixation, percentage protein of dry cells, efficiency of nitrogen fixation and bacterial dry weight of both strains (Table 2). In addition, residual malate in the supernatant was increased to a concentration that suggested that malate was no longer limiting. With these high oxygen concentrations, when malate was not limiting, the strains differed in their response to $\mathrm{O}_{2}$ (Table 2). Cell dry weight and efficiency of nitrogen-fixation of the carotenoid-overproducing mutant $\mathrm{Cl}$ were significantly higher and the residual malate concentration was significantly lower than for the wild-type strain Sp7. This specific response of the mutant was accompanied by a marked increase in carotenoid synthesis. In contrast, $\mathrm{Sp} 7 \mathrm{did}$ not produce carotenoids in significant amounts (Table 2).

\section{DISCUSSION}

The purpose of this investigation was to evaluate the contribution of carotenoids to the oxygen tolerance of the extremely oxygen-sensitive nitrogen fixation of $A$. brasilense, by comparing the pale wild-type $\mathrm{Sp} 7$ with carotenoid-overproducing red mutants. We demonstrated a significant contribution of a high carotenoid content to the protection of nitrogen-limited $A$. brasilense against oxygen damage. It is quite possible that the carotenoids supported the recovery process from the oxygen shock, eventually enabling the bacteria to start nitrogen fixation. Under various conditions of mild oxygen stress (Table 1, Fig. 2) the carotenoid-overproducing mutants grew better than the wild-type. The efficiency of nitrogen fixation and the total amount of nitrogen fixed was significantly higher in the mutant $\mathrm{Cl}$ than in the wild-type under oxygen stress (Table 2). However, the presence of high levels of carotenoids did not alter the general pattern of growth inhibition in $\mathrm{N}_{2}$-fixing chemostat cultures at increased oxygen concentrations. Apparently carotenoids make no major contribution to the oxygen tolerance of the nitrogen-fixation system.

Carotenoid overproduction was also found in some mutants of $A$. lipoferum SpRG20a after Tn 5 transposon mutagenesis (Abdel-Salam \& Klingmüller, 1987). In some ordinary light pink strains of $A$. brasilense, deep red mutants occurred spontaneously (Tarrand et al., 1978). Possibly the carotenoid-overproducing mutants are altered in a regulatory gene (or site) analogous to the carS gene in Phycomyces (Cerda-Olmedo \& Torres-Martinez, 1979), whose mutation caused overproduction of carotenoids. The ability to synthesize carotenoids may be quite common in Azospirillum as a cryptic property left from a common ancestor. Azospirillum spp. are taxonomically closely related to the photosynthetic bacterium Rhodospirillum rubrum (Woese $e t$ al., 1982; Reinhold et al., 1987), which contains carotenoids that function in its photosynthetic apparatus and protect against photo-oxidation damage. Interestingly, carotenoid biosynthesis in $A$. brasilense was triggered under oxygen stress conditions (Table 2). Under nitrogen-limiting conditions (Fig. 2), the organism may also experience oxygen stress because of the concomitant decline in respiration.

Differences in oxygen tolerance of Azospirillum have been demonstrated at the species level (Hartmann et al., 1985; Fu \& Knowles, 1986) and the strain level (Hurek et al., 1987), but there was no obvious correlation with pigmentation. Bothe et al. (1983) failed to demonstrate a contribution of carotenoids to oxygen protection, when they compared differently pigmented wild-type strains ( $A$. brasilense $\mathrm{Sp} 7$ and $\mathrm{SpCd}$ ). Differences in oxygen tolerance due to other protective activities may have overshadowed the small effect of carotenoids.

In a number of nitrogen-fixing bacteria, including Azospirillum (Yates \& Jones, 1974; Hochmann \& Burris, 1981; Goldberg et al., 1987; Hartmann \& Burris, 1987), the rapid and partially reversible inhibition of nitrogen fixation by oxygen may result from a shortage of electrons, because the limited supply has been diverted for respiration or production of poly- $\beta$ hydroxybutyrate, which accumulates under oxygen stress in Azospirillum (Hurek et al., 1987). Therefore the inhibition of nitrogen fixation by increased oxygen concentrations may be caused primarily by a mechanism which does not involve the direct toxic effects of oxygen or oxygen 
metabolites. An increased production of reducing equivalents, enabling cells to respire at enhanced rates and to fix nitrogen simultaneously, may be the key to improved oxygen tolerance in Azospirillum, as is the case in Azotobacter (Ramos \& Robson, 1985). In concert with other protective mechanisms, carotenoids play only a limited role, but they may be of some ecological advantage to the poorly oxygen protected nitrogen-fixing $A$. brasilense in certain oxygen stress situations.

We thank Professor R. H. Burris (Madison, Wisconsin, USA) for generous support and for helpful discussions. A.H. was supported by a fellowship of the Deutsche Forschungsgemeinschaft (Ha 1241/2). T. H. is indebted to Professor E.-G. Niemann for continuous interest and support.

\section{REFERENCES}

Abdel-Salam, M. S. \& Klingmüller, W. (1987). Transposon Tn5 mutagenesis in Azospirillum lipoferum: isolation of indole acetic acid mutants. Molecular and General Genetics 210, 165-170.

Adelberg, E. A., Mandel, M. \& Chen, G. C. C. (1965). Optimal conditions for mutagenesis by $N$ methyl- $N^{\prime}$-nitro- $N$-nitrosoguanidine in Escherichia coli K-12. Biochemical and Biophysical Research Communications 18, 788-795.

AlbReCHT, S. L. \& OKon, Y. (1980). Cultures of Azospirillum. Methods in Enzymology 69, 740-749.

Barak, R., Nur, I., Okon, Y. \& Henis, Y. (1982). Aerotactic response of Azospirillum brasilense. Journal of Bacteriology 152, 643-649.

Bergersen, F. J. (1980). Measurement of nitrogen fixation by direct means. In Methods for Evaluating Biological Nitrogen Fixation, pp. 65-110. Edited by F. J. Bergersen. Toronto: Wiley.

Bergersen, F. J. \& Turner, G. L. (1980). Properties of terminal oxidase systems of bacteroids from root nodules of soybean and cowpea and of $\mathbf{N}_{2}$-fixing bacteria grown in continuous culture. Journal of General Microbiology 118, 235-252.

Bothe, H., BARbosa, G. \& DÖBEREINER, J. (1983). Nitrogen fixation and nitrate respiration of Azospirillum brasilense. Zeitschrift für Naturforschung 38c, 571-577.

BritTon, G. \& Goodwin, T. W. (1971). Biosynthesis of carotenoids. Methods of Enzymology 18, 654-701.

BURRIS, R. H. (1974). Methodology. In The Biology of Nitrogen Fixation, pp. 3-42. Edited by A. Quispel. Amsterdam: North Holland Publishing Co.

BuRton, G. W. \& INGOLD, K. U. (1984). $\beta$-Carotene: an unusual type of lipid antioxidant. Science 224, 569-573.

Cerda-Olmedo, E. \& Torres-Martinez, S. (1979). Genetics and regulation of carotene biosynthesis. Pure and Applied Chemistry 51, 631-637.

DAY, J. M. \& DöBEReINER, J. (1976). Physiological aspects of $\mathrm{N}_{2}$-fixation by a Spirillum from Digitaria roots. Soil Biology and Biochemistry 8, 45-50.

FAWCETT, J. K. \& SCOTT, J. E. (1960). A rapid and precise method for determination of urea. Journal of Clinical Pathology 13, 156-159.

Fu, C. \& KNowLES, R. (1986). Oxygen tolerance of uptake hydrogenase in Azospirillum spp. Canadian Journal of Microbiology 32, 897-900.

Goldberg, I., NaDler, V. \& Hochman, A. (1987). Mechanism of nitrogenase switch-off by oxygen. Journal of Bacteriology 169, 874-879.
Halliwell, B. \& Gutteridge, J. M. C. (1984). Oxygen toxicity, oxygen radicals, transition metals and disease. Biochemical Journal 219, 1-14.

HARTMANN, A. \& BuRRIS, R. H. (1987). Regulation of nitrogenase activity by oxygen in Azospirillum brasilense and Azospirillum lipoferum. Journal of Bacteriology 169, 944-948.

Hartmann, A., Fusseder, A. \& Klingmüller, W. (1983). Mutants of Azospirillum affected in nitrogen fixation and auxin production. In Azospirillum II, Genetics, Physiology, Ecology (Experientia Supplementum, vol. 48), pp. 78-88. Edited by W. Klingmüller. Basel: Birkhäuser-Verlag.

Hartmann, A., Fu, H., Song, S.-D. \& BurRis, R. H. (1985). Comparison of nitrogenase regulation in $A$. brasilense, $\boldsymbol{A}$. lipoferum and $\boldsymbol{A}$. amazonense. In Azospirillum III, Genetics, Physiology, Ecology, pp. 116-126. Edited by W. Klingmüller. Berlin : Springer Verlag.

Hochman, A. \& BURRIS, R. H. (1981). Effect of oxygen on acetylene reduction by photosynthetic bacteria. Journal of Bacteriology 147, 492-499.

Hochman, A., Goldberg, I., Nadler, V. \& HaRTMANN, A. (1987). The reversible inhibition of nitrogen fixation by oxygen. In Inorganic Nitrogen Metabolism, pp. 173-174. Edited by W. R. Ullrich, P. J. Aparicio, P. J. Syrett \& F. Castillo. Berlin: Springer Verlag.

HuREX, T., ReINHOLd, B., Fendrix, I. \& NiemanN, E.G. (1987). Root-zone-specific oxygen tolerance of Azospirillum spp. and diazotrophic rods closely associated with Kallar grass. Applied and Environmental Microbiology 53, 163-169.

Kloss, M., Iwannek, K. H. \& Fendrik, I. (1983). Physiological properties of Azospirillum brasilense Sp7 in a malate limited chemostat. Journal of General and Applied Microbiology 29, 447-457.

KRIEG, N. R. \& DöBEREINER, J. (1984). Genus Azospirillum Tarrand, Krieg and Döbereiner 1979, 79AL (effective publication: Tarrand, Krieg and Döbereiner 1978, 967). In Bergey's Manual of Systematic Bacteriology, vol. 1, pp. 94-104. Edited by N. R. Krieg. Baltimore: Williams \& Wilkins.

KRIEG, N. R. \& Hoffman, P. S. (1986). Microaerophily and oxygen toxicity. Annual Review of Microbiology 40, 107-130.

KRINSKY, N. I. (1979). Carotenoid protection against oxidation. Pure and Applied Chemistry 51, 649-660.

MOORE, E. R. B., Norrod, E. P. \& JURTShUK, P. (1984). Superoxide dismutases of Azotobacter vine- 
landii and other aerobic, free-living nitrogen-fixing bacteria. FEMS Microbiology Letters 24, 261-265.

Nelson, L. M. \& KNowles, R. (1978). Effect of oxygen and nitrate on nitrogen fixation and denitrification by Azospirillum brasilense grown in continuous culture. Canadian Journal of Microbiology 24, 13951403.

Nur, I., Steinitz, Y. L., Okon, Y. \& Henis, Y. (1981). Carotenoid composition and function in nitrogenfixing bacteria of the genus Azospirillum. Journal of General Microbiology 122, 27-32.

NuR, I., OKon, Y. \& HeNIS, Y. (1982). Effect of dissolved oxygen tension on production of carotenoids, poly- $\beta$-hydroxybutyrate, succinate oxidase and superoxide dismutase by Azospirillum brasilense Cd grown in continuous culture. Journal of General Microbiology 128, 2937-2943.

OKon, Y., Houchins, J. P., Albrecht, S. L. \& Burris, R. H. (1977). Growth of Spirillum lipoferum at constant partial pressures of oxygen, and the properties of its nitrogenase in cell-free extracts. Journal of General Microbiology 98, 87-93.

Oxon, Y., NUR, I. \& HeNIS, Y. (1983). Effect of oxygen concentration on electron transport components and microaerobic properties of Azospirillum brasilense. In Azospirillum II, Genetics, Physiology, Ecology (Experientia Supplementum, vol. 48), pp. 115-126. Edited by W. Klingmüller. Basel: Birkhäuser Verlag.

Patriquin, D. G., Döbereiner, J. \& Jain, D. K. (1983). Sites and processes of association between diazotrophs and grasses. Canadian Journal of Microbiology 29, 900-915.

RAMOS, J. L. \& RoBSON, R. L. (1985). Lesions in citrate synthase that affect aerobic nitrogen fixation by Azotobacter chroococcum. Journal of Bacteriology 162, 746-751.

ReInhold, B., Hurek, T., Fendrik, I., Pot, B., Gillis, M., Kersters, K., Thielemans, S. \& DE LEY, J. (1987). Azospirillum halopraeferens sp. nov., a nitrogen-fixing organism associated with roots of Kallar grass (Leptochloa fusca (L.) Kunth). International Journal of Systematic Bacteriology 37, 43-51.

Robson, L. \& Postgate, J. R. (1980). Oxygen and hydrogen in biological nitrogen fixation. Annual Review of Microbiology 34, 183-207.

Stouthamer, A. H., De VRies, W. \& Niekus, H. G. D. (1979). Microaerophily. Antonie van Leeuwenhoek 45, 5-12.

TARRAND, J. J., KRIEG, N. R. \& DÖBEREINER, J. (1978). A taxonomic study of the Spirillum lipoferum group, with descriptions of a new genus, Azospirillum gen. nov, and two species, Azospirillum lipoferum (Beijerinck) comb. nov. and Azospirillum brasilense sp. nov. Canadian Journal of Microbiology 24, 967-980.

Woese, C. R., Blanz, P., Hespeli, R. B. \& Hahn, C. M. (1982). Phylogenetic relationship among various helical bacteria. Current Microbiology 7, 119-124.

YATES, M. G. \& JONES, C. W. (1974). Respiration and nitrogen fixation in Azotobacter. Advances in Microbial Physiology 11, 97-135. 